\title{
Hyperbaric oxygen therapy of spinal cord injury
}

\author{
Nitesh P. Patel ${ }^{1}$, Jason H. Huang ${ }^{1,2, *}$ \\ 1 Texas A\&M College of Medicine, Temple, Texas, USA \\ 2 Department of Neurosurgery, Baylor Scott \& White Healthcare, Temple, Texas, USA \\ *Correspondence to: Jason H. Huang, M.D., jhuang@tamuhsc.edu or jasonhhuang@yahoo.com. \\ orcid: 0000-0002-4426-0168 (Jason H. Huang)
}

\section{Abstract}

Spinal cord injury (SCI) is a complex disease process that involves both primary and secondary mechanisms of injury and can leave patients with devastating functional impairment as well as psychological debilitation. While no curative treatment is available for spinal cord injury, current therapeutic approaches focus on reducing the secondary injury that follows SCI. Hyperbaric oxygen (HBO) therapy has shown promising neuroprotective effects in several experimental studies, but the limited number of clinical reports have shown mixed findings. This review will provide an overview of the potential mechanisms by which HBO therapy may exert neuroprotection, provide a summary of the clinical application of HBO therapy in patients with SCI, and discuss avenues for future studies.

Key words: spinal cord injury; hyperbaric oxygen therapy; preconditioning; apoptosis; inflammation; oxidative stress; angiogenesis; spinal cord edema; autophagy

doi: $10.4103 / 2045-9912.208520$

How to cite this article: Patel NP, Huang JH. Hyperbaric oxygen therapy of spinal cord injury. Med Gas Res. 2017;7(2):133-143.

\section{INTRODUCTION}

Spinal cord injury (SCI) can result from various etiologies, but a common feature is the potential for functional and psychological devastation following injury. Between 1993 and 2012, a total of 63,109 patients were afflicted by acute traumatic SCI in the United States based on the Nationwide Inpatient Sample (NIS) database. ${ }^{1}$ In 2016, the prevalence of SCI in the United States was reported to be approximately 282,000 people with an incidence of 17,000 people per year. ${ }^{2}$ The average age at injury has risen from 29 years in the 1970s to 42 years in 2016, and there is a four-fold higher incidence in males versus females. ${ }^{2}$ The current length of hospital stay after SCI is 11 days, however, approximately $30 \%$ of affected patients are re-hospitalized for an average of 22 days, most commonly due to genitourinary disease. ${ }^{2}$ While the total cost of caring for patients with SCI has been estimated to be over $\$ 7$ billion annually in the United States, this figure does not represent the immense suffering and life-changing deficits that can result from SCI. ${ }^{2}$

The pathophysiology of SCI involves both primary and secondary damage. ${ }^{3}$ Primary damage involves the inciting mechanical injury, whereas secondary damage is delayed and involves a variety of pathophysiologic processes, including apoptosis, oxidative stress, ischemia, edema, inflammation, and excitotoxicity. ${ }^{3-5}$ While primary injury is often irreversible, prior studies have shown that the mechanisms of secondary injury can be targeted to improve neurological outcomes. ${ }^{3}$ Methylprednisolone is the typical drug of choice to treat secondary injury after SCI, but its' side effects warrant investigation of safer treatment modalities. ${ }^{6}$ One such option is hyperbaric oxygen (HBO) therapy, in which $100 \%$ oxygen is administered at a pressure between one and three times that of atmospheric pressure. Previous experimental and clinical studies have demonstrated the beneficial effects of HBO therapy, administered either before (preconditioning) or after SCI, on recovery of motor function, improvement of spinal cord histology, and attenuation of secondary injury mechanisms. This review seeks to outline the results of these experimental and clinical studies involving HBO therapy of SCI, either via preconditioning or post-SCI treatment, as well as to detail the proposed neuroprotective mechanisms and discuss avenues for further research.

\section{Experimental Studies: Potential Mechanisms of HBO NeURoprotection}

Given that ischemia is one of the most significant 
mechanisms involved in secondary injury after SCI, a treatment modality that increases the oxygen tension of the injured spinal cord should theoretically help improve recovery. ${ }^{3,7}$ The majority of oxygen in arterial blood is carried by hemoglobin and a smaller fraction is dissolved in plasma; oxygen that is administered at an increased pressure can increase the amount of dissolved oxygen, creating a larger pressure gradient that can drive oxygen into ischemic tissue ${ }^{8-10}$ Accordingly, in 1972, HBO applied to a SCI model in dogs showed significantly increased oxygen tension in the spinal cord and a correlation with significantly improved functional recovery. ${ }^{11}$

While oxygen availability plays a pivotal role in cell survival following SCI, further pathophysiologic pathways involved in the secondary injury following SCI have been proposed. ${ }^{3,12-14}$ Experimental studies that have investigated the effect of HBO therapy on these pathways propose that the neuroprotection afforded by HBO therapy involves the following broad mechanisms: 1) decreasing apoptosis; 2) reducing oxidative stress; 3 ) diminishing inflammation; 4) promoting angiogenesis; 5) reducing spinal cord edema; 6) increasing autophagy. An overview of these potential neuroprotective mechanisms is provided in this review (Table 1).

\section{HBO therapy decreases apoptosis via various mediators}

Cells that survive the primary injury from SCI are susceptible to secondary damage, particularly via apoptosis, which has been observed to persist for several weeks after $\mathrm{SCI}$ and thus is an attractive target for intervention. ${ }^{38}$ Many studies have used terminal deoxynucleotidyl transferase (TdT) dUTP nick-end labeling (TUNEL) staining to show that HBO therapy significantly reduces apoptosis in injured spinal cord tissue, and most of the studies have proposed potential pathways by which HBO therapy attenuates apoptotic cell death after SCI. . $^{15,19,20,23,27,30,31,33}$

Inducible nitric oxide synthase (iNOS) has been shown to induce apoptosis by increasing nitric oxide after SCI, and in 2004, Yu et al. ${ }^{15,39}$ suggested that HBO therapy decreases apoptosis after traumatic SCI by downregulating the hypoxia-induced expression of the iNOS gene; this was evidenced by significantly decreased numbers of iNOS-positive cells at 1 and 2 days post-SCI in the group that received a single session of HBO therapy administered 30 minutes after SCI compared to the SCI only group.

The inflammatory cytokines, interleukin (IL)-1 $\beta$ and tumor necrosis factor (TNF)- $\alpha$, have been implicated in apoptosis after SCI. ${ }^{40-42}$ In 2010, a rat model of SCI via spinal cord compression by an aneurysm clip at $\mathrm{T}_{8-9}$ resulted in significantly increased levels of IL- $1 \beta$ and TNF- $\alpha$ at four hours post-SCI in animals that received normobaric air; however, these cytokines were significantly reduced in the group that received 120 minutes of HBO therapy at 2.5 ATA (approximately $245 \mathrm{kPa}$ ) immediately after SCI, a finding that was also accompanied by decreased apoptosis by TUNEL staining, suggesting that the attenuation of apoptosis by HBO therapy may be related to downregulation of IL-1 $\beta$ and TNF- $\alpha .^{20}$

In 2014, Long et al..$^{30}$ studied the role of the pro-apoptotic protein adaptor molecule apoptosis-associated speck-like protein (ASC), in the neuroprotection provided by $\mathrm{HBO}$ therapy. It is known that activation of NACHT domain-, leucine-rich-repeat- and pyrin domain-containing protein 3 (NALP3) via oxidative stress leads to activation and binding of ASC, which subsequently recruits caspase- 8 to form a ternary complex that triggers apoptosis. ${ }^{43,44}$ Long et al. ${ }^{30}$ showed that mRNA and protein expression of ASC increases after SCI but is significantly decreased by daily HBO therapy started immediately after SCI, suggesting that HBO prevents formation of the ternary complex by attenuating oxidative stress.

Endoplasmic reticulum (ER) stress is another mechanism by which oxidative stress plays a role in apoptosis after SCI. ${ }^{33}$ CCAAT-enhancer-binding protein homologous protein $(\mathrm{CHOP})$ is a transcription factor that has shown to be a key player in ER stress-induced apoptosis. ${ }^{45}$ In addition, caspase-12 is an ER-associated caspase that also mediates apoptosis via ER stress. ${ }^{46} \mathrm{~A}$ variety of mechanisms activate caspase-12, which in turn activates caspase-3, a cytoplasmic protein that is an executioner of apoptosis. ${ }^{47} \mathrm{In}$ the study by Liu et al., ${ }^{33} \mathrm{mRNA}$ and protein levels of CHOP, caspase-12, and caspase- 3 were all increased in SCI-only rats compared to controls; however, the upregulation of these three factors was mitigated in the group that received daily HBO treatments at 2.0 ATA starting 6 hours after SCI, suggesting that HBO therapy attenuates SCI-induced neuronal apoptosis by downregulating the ER-stress-induced apoptotic pathway.

In 2009, Wang et al. ${ }^{19}$ studied the effects of HBO preconditioning (HBO-PC) on apoptosis after SCI. HBO-PC led to higher levels of mitochondrial Bcl-2, an anti-apoptotic protein, both prior to ischemia-reperfusion injury and during the reperfusion period; furthermore, pro-apoptotic cytochrome $\mathrm{c}$ release from mitochondria and levels of caspase-3 and caspase-9 were decreased during reperfusion. These effects were all reversed by L-nitroarginine-methyl-ester (LNAME), a nonspecific nitric oxide synthase (NOS) inhibitor, indicating that nitric oxide appears to be an important factor in the anti-apoptotic effects of HBO-PC. ${ }^{19}$ However, the study by Yu et al. ${ }^{15}$ suggested that HBO therapy post-SCI reduced apoptosis by inhibiting hypoxia-induced iNOS, implying that nitric oxide is a mediator of apoptosis. It is known that nitric oxide has contrasting effects depending on 
Table 1: Functional, histological, and biochemical findings of experimental studies

\begin{tabular}{|c|c|c|c|c|}
\hline Author & Year & Functional outcomes & Histological findings & Biochemical findings \\
\hline Yu et al. ${ }^{15}$ & 2004 & Not assessed & $\begin{array}{l}\text { Decreased apoptosis by TUNEL } \\
\text { staining }\end{array}$ & $\begin{array}{l}\text { Downregulation of iNOS \& GDNF gene } \\
\text { expression }\end{array}$ \\
\hline Nie et al. ${ }^{16}$ & 2006 & $\begin{array}{l}\text { Improved motor recovery indicated by } \\
\text { higher modified Tarlov scores }\end{array}$ & $\begin{array}{l}\text { Increased neuron number \& improved } \\
\text { neuronal histology; reversed by AT }\end{array}$ & $\begin{array}{l}\text { Increased activities of catalase, } \\
\text { superoxide dismutase, \& glutathione } \\
\text { peroxidase; decreased MDA }\end{array}$ \\
\hline $\begin{array}{l}\text { Kahraman } \\
\text { et al. }{ }^{17}\end{array}$ & 2007 & Not assessed & Not assessed & $\begin{array}{l}\text { Increased superoxide dismutase \& } \\
\text { decreased TBARS compared to } \\
\text { methylprednisolone }\end{array}$ \\
\hline Li et al. ${ }^{18}$ & 2007 & Not assessed & Not assessed & $\begin{array}{l}\text { Increased protein \& mRNA expression } \\
\text { of heme oxygenase-1, increased cell } \\
\text { viability, decreased DNA damage }\end{array}$ \\
\hline Wang et al. ${ }^{19}$ & 2009 & $\begin{array}{l}\text { Increased recovery of neurological } \\
\text { function indicated by a 15-point } \\
\text { scale }\end{array}$ & $\begin{array}{l}\text { Decreased apoptosis by } \\
\text { TUNELstaining; fewer injured } \\
\text { neurons indicated by Nissl staining }\end{array}$ & $\begin{array}{l}\text { Increased antioxidant enzymes (Mn- } \\
\text { SOD \& catalase), pre-ischemic Bcl- } \\
2 \text { expression, \& NO; decreased } \\
\text { cytochrome c release and caspases } 3 \& \\
9 \text { during reperfusion. All reversed by } \\
\text { L-NAME }\end{array}$ \\
\hline Tai et al. ${ }^{20}$ & 2010 & $\begin{array}{l}\text { Decreased hindlimb motor deficits } \\
\text { indicated by higher BBB scores }\end{array}$ & $\begin{array}{l}\text { Decreased apoptosis by TUNEL } \\
\text { staining; diminished spinal cord } \\
\text { infarct }\end{array}$ & $\begin{array}{l}\text { Decreased VEGF, GDNF, pro- } \\
\text { inflammatory cytokines (IL- } 1 \beta \text { and } \\
\text { TNF- } \alpha \text { ), \& MPO }\end{array}$ \\
\hline $\begin{array}{l}\text { Topuz } \\
\text { et al. }{ }^{21}\end{array}$ & 2010 & $\begin{array}{l}\text { Improved motor recovery indicated by } \\
\text { greater performance on incline plane }\end{array}$ & $\begin{array}{l}\text { Reduced level of hemorrhage, } \\
\text { necrosis, and edema; increased }\end{array}$ & $\begin{array}{l}\text { Decreased MDA; increased glutathione } \\
\text { peroxidase, catalase, and superoxide } \\
\text { dismutase }\end{array}$ \\
\hline $\begin{array}{l}\text { Dayan } \\
\text { et al. }\end{array}$ & 2012 & $\begin{array}{l}\text { Improved motor recovery indicated by } \\
\text { higher BBB scores }\end{array}$ & Not assessed & $\begin{array}{l}\text { Decreased superoxide dismutase, } \\
\text { glutathione peroxidase, NO, and NOS }\end{array}$ \\
\hline Lu et al..$^{23}$ & 2012 & $\begin{array}{l}\text { Improved motor recovery indicated } \\
\text { by higher BBB scores; improved } \\
\text { conduction along descending \& } \\
\text { ascending spinal cord tracts indicated } \\
\text { by decreased MEP \& SEP latencies }\end{array}$ & $\begin{array}{l}\text { Decreased apoptosis by TUNEL } \\
\text { staining; enhanced axonal growth } \\
\text { indicated by increased HRP- } \\
\text { positive and BDA-positive fibers } \\
\text { near SCI site; increased number \& } \\
\text { size of reactive }\end{array}$ & Not assessed \\
\hline Yang et al..$^{24}$ & 2013 & $\begin{array}{l}\text { Improved motor recovery indicated by } \\
\text { higher BBB scores }\end{array}$ & Not assessed & $\begin{array}{l}\text { Increased VEGF expression; decreased } \\
\text { expression of MMP-2, MMP-9, and } \\
\text { IL-6; decreased edema indicated by } \\
\text { significantly reduced spinal cord water } \\
\text { content }\end{array}$ \\
\hline Yang et al..$^{25}$ & 2013 & $\begin{array}{l}\text { Improved motor recovery indicated by } \\
\text { higher BBB scores }\end{array}$ & Not assessed & $\begin{array}{l}\text { Significantly decreased mRNA \& protein } \\
\text { expression of HMGB1 \& NF- } \mathrm{B} B\end{array}$ \\
\hline Tan et al. ${ }^{26}$ & 2014 & $\begin{array}{l}\text { Improved motor recovery indicated by } \\
\text { higher BBB scores }\end{array}$ & Improved histological scores & $\begin{array}{l}\text { Significantly decreased IL- } 1 \beta, \mathrm{TNF}-\alpha, \\
\text { and mRNA \& protein expression of NF- } \\
\kappa \mathrm{B} \text { p } 65 \text { protein }\end{array}$ \\
\hline $\mathrm{Xu}$ et al. ${ }^{27}$ & 2014 & $\begin{array}{l}\text { Improved motor recovery indicated } \\
\text { by higher BBB scores; improved } \\
\text { electrophysiology indicated by } \\
\text { reduced MEP latency }\end{array}$ & $\begin{array}{l}\text { Decreased apoptosis by } \\
\text { TUNEL staining; greater Nrf2 } \\
\text { immunoreactivity in astrocytes } \\
\text { versus neurons }\end{array}$ & $\begin{array}{l}\text { Decreased edema indicated by reduced } \\
\text { spinal cord water content; decreased } \\
\text { enzymatic activity of caspases-3 \& } \\
-9 \text {; increased Nrf2 mRNA/protein } \\
\text { expression, DNA binding, and } \\
\text { expression of downstream genes both in } \\
\text { vivo and in vitro; increased glutathione } \\
\text { content }\end{array}$ \\
\hline $\begin{array}{l}\text { Huang } \\
\text { et al. }^{29}\end{array}$ & & Not assessed & $\begin{array}{l}\text { Increased neuronal HSP } 32 \text { expression } \\
\text { confirmed via immunostaining }\end{array}$ & $\begin{array}{l}\text { Increased HSP32 expression; reversed by } \\
\text { Zn-pp }\end{array}$ \\
\hline Liu et al. ${ }^{28}$ & 2014 & $\begin{array}{l}\text { Improved motor recovery indicated by } \\
\text { higher BBB scores }\end{array}$ & $\begin{array}{l}\text { Significantly attenuated histological } \\
\text { changes }\end{array}$ & $\begin{array}{l}\text { Increased VEGF expression; } \\
\text { downregulation of CX43 mRNA \& } \\
\text { protein }\end{array}$ \\
\hline Long et al. ${ }^{30}$ & 2014 & $\begin{array}{l}\text { Improved motor recovery indicated by } \\
\text { higher BBB scores }\end{array}$ & $\begin{array}{l}\text { Decreased apoptosis by TUNEL } \\
\text { staining; decreased expression of } \\
\text { ASC }\end{array}$ & $\begin{array}{l}\text { Decreased mRNA \& protein expression } \\
\text { of ASC; decreased caspase- } 3 \text { expression }\end{array}$ \\
\hline Wang et al. ${ }^{31}$ & 2014 & $\begin{array}{l}\text { Improved motor function indicated by } \\
\text { higher BBB scores }\end{array}$ & $\begin{array}{l}\text { Decreased apoptosis by TUNEL } \\
\text { staining; greater number of NF-200 } \\
\text { positive nerve fibers by IHC }\end{array}$ & $\begin{array}{l}\text { Reduced mRNA \& protein expression of } \\
\text { AQP4 \& AQP9 }\end{array}$ \\
\hline
\end{tabular}




\begin{tabular}{|c|c|c|c|c|}
\hline Author & Year & Functional outcomes & Histological findings & Biochemical findings \\
\hline Geng et al. ${ }^{32}$ & 2015 & $\begin{array}{l}\text { Improved motor recovery } \\
\text { indicated by higher BBB } \\
\text { scores }\end{array}$ & $\begin{array}{l}\text { Greater myelin sparing and improved } \\
\text { axonal regeneration }\end{array}$ & $\begin{array}{l}\text { Decreased iNOS and CD 16/32 positive cells } \\
\text { (M1 phenotype) and increased arginase-1 } \\
\text { and CD206 positive cells (M2 phenotype); } \\
\text { decreased Th1 cytokines (IFN- } \gamma \text { and TNF- } \alpha \text { ) } \\
\text { and increased Th2 cytokines (IL-4 and IL-13) }\end{array}$ \\
\hline Kang et al. ${ }^{34}$ & 2015 & $\begin{array}{l}\text { Improved motor recovery } \\
\text { indicated by higher BBB } \\
\text { scores }\end{array}$ & Not assessed & $\begin{array}{l}\text { Significantly decreased mRNA \& protein } \\
\text { expression of TLR4; significantly decreased } \\
\text { HMGB1 and NF-kB }\end{array}$ \\
\hline Liang et al. ${ }^{35}$ & 2015 & $\begin{array}{l}\text { Improved motor recovery } \\
\text { indicated by higher BBB } \\
\text { scores }\end{array}$ & Not assessed & $\begin{array}{l}\text { Decreased mRNA \& protein expression of } \\
\text { NALP3, caspase-1, and ASC; decreased IL-1 } \beta \\
\text { release }\end{array}$ \\
\hline Liu et al. ${ }^{33}$ & 2015 & $\begin{array}{l}\text { Improved motor function } \\
\text { indicated by higher BBB } \\
\text { scores }\end{array}$ & $\begin{array}{l}\text { Decreased apoptosis by TUNEL } \\
\text { staining }\end{array}$ & $\begin{array}{l}\text { Decreased mRNA \& protein expression of } \\
\text { CHOP, caspase- } 3 \text { and caspase- } 12\end{array}$ \\
\hline Sun et al. ${ }^{36}$ & 2016 & $\begin{array}{l}\text { Improved motor recovery } \\
\text { indicated by higher BBB } \\
\text { scores }\end{array}$ & $\begin{array}{l}\text { TEM: loose RER, increased free } \\
\text { ribosomes, mitochondrial swelling, } \\
\text { numerous autophagosomes }\end{array}$ & $\begin{array}{l}\text { Significantly increased Beclin-1 \& LC3-II, } \\
\text { indicating increased autophagy }\end{array}$ \\
\hline Wang et al. ${ }^{37}$ & 2016 & $\begin{array}{l}\text { Improved motor recovery } \\
\text { indicated by higher BBB } \\
\text { scores }\end{array}$ & Not assessed & $\begin{array}{l}\text { Significantly decreased mRNA \& protein levels } \\
\text { of RAGE and MCP-1 }\end{array}$ \\
\hline \multicolumn{5}{|c|}{$\begin{array}{l}\text { Note: BBB: Basso, Beattie, Bresnahan Locomotor scale; TUNEL: terminal deoxynucleotidyl transferase dUTP nick-end labeling; iNOS: inducible } \\
\text { nitric oxide synthase; GDNF: glial derived neurotropic factor; VEGF: vascular endothelial growth factor; IL: interleukin; TNF: tumor necrosis factor; } \\
\text { MPO: myeloperoxidase; CHOP: CCAAT-enhancer-binding protein homologous protein; NF-200: neurofilament-200; IHC: immunohistochemistry; } \\
\text { AQP: aquaporin; Mn-SOD: manganese superoxide dismutase; Bcl-2: b cell lymphoma 2; L-NAME: Lnitroarginine-methyl-ester; ASC: adaptor } \\
\text { molecule apoptosis-associated speck-like protein; NALP3: NACHT domain-, leucine-rich-repeat- and pyrin domain-containing protein 3; MEP: } \\
\text { motor-evoked potential; SEP: somatosensory-evoked potential; HRP: horseradish peroxidase; BDA: biotin dextran amine; SCI: spinal cord injury; } \\
\text { Nrf2: nuclear factor erythroid 2-related factor 2; AT: 3-amino-1,2,4-triazole; MDA: malondialdehyde; NO: nitric oxide; NOS: nitric oxide synthase; } \\
\text { TBARS: thiobarbituric acid reactive substances; HSP32: heat shock protein 32 (heme oxygenase-1); Zn-pp: zinc protoporphyrin IX; CX43: Connexin43; } \\
\text { MMP: matrix metalloproteinase; IFN: interferon; TLR4: toll like receptor 4; HMGB1: high-mobility group protein B1; NF-kB: nuclear factor kappa } \\
\text { B; RAGE: receptor for advanced glycation end products; MCP-1: monocyte chemoattractant protein-1; TEM: transmission electron microscope; RER: } \\
\text { rough endoplasmic reticulum; LC3-II: light chain } 3 \text { type II. }\end{array}$} \\
\hline
\end{tabular}

the amount present: high concentrations in the micromolar range are seen in inflammation, whereas smaller amounts are important in the neuroprotection created by various preconditioning methods. ${ }^{48,49}$ The study by Wang et al. ${ }^{19}$ observed nitric oxide production in the nanomolar range after HBO-PC, indicating that small amounts of nitric oxide can induce mechanisms involved in the tolerance induced by HBO-PC. Another preconditioning study in 2012 also demonstrated decreased neuronal apoptosis after SCI, indicating the potential use of HBO-PC to provide neuroprotection prior to neurosurgical procedures involving the spinal cord..$^{23}$

\section{HBO therapy decreases oxidative stress and lipid peroxidation}

Free radical generation occurs early after SCI and plays a key role in secondary injury. ${ }^{12}$ The central nervous system is particularly susceptible to the oxidative stress due to its high lipid content; accordingly, lipid peroxidation is a significant component of secondary injury after SCI and a popular target of pharmacological intervention. ${ }^{3}$ Many studies have shown the ability of HBO therapy to attenuate oxidative stress, but few have studied the exact mechanism by which HBO therapy affects lipid peroxidation.

Malondialdehyde (MDA) is a marker of lipid peroxidation after SCI.$^{50}$ In a 2006 study of spinal cord ischemiareperfusion injury via aortic cross-clamping in rabbits, once daily HBO-PC for 5 days resulted in significantly lowered MDA levels after SCI in the HBO-PC group, with concomitant increases in catalase and superoxide dismutase. ${ }^{16}$ These findings correlated with improved motor recovery indicated by higher modified Tarlov scores in the HBO-PC group, suggesting that HBO-PC protects against free-radical mediated lipid peroxidation and improves neurological outcomes by upregulating antioxidant enzymes. ${ }^{16}$ Unlike the ischemia-reperfusion injury and HBO-PC paradigm used by Nie et al., ${ }^{16}$ the study by Topuz et al. ${ }^{21}$ in 2010 involved a single 90 -minute HBO treatment immediately after SCI secondary to clip compression of the spinal cord. HBO therapy increased activities of glutathione peroxidase, superoxide dismutase, and catalase, while significantly attenuating MDA levels compared to the SCI only group, further suggesting that HBO therapy can decrease lipid peroxidation by upregulating antioxidant enzymes; furthermore, these findings were accompanied by improved neurological recovery indicated by higher 
scores on the inclined plane test, signifying that HBO therapy improves neurological outcomes by diminishing oxidative stress. ${ }^{21}$ An earlier study in 2007 measured levels of thiobarbituric acid reactive substances (TBARS) to monitor lipid peroxidation in a rat SCI model involving clip compression at $\mathrm{T}_{8-10}$ and showed that TBARS were significantly higher in the SCI only group versus shamoperated rats. ${ }^{17}$ While methylprednisolone showed no significant effect on these levels when administered after SCI, HBO therapy at 2.8 ATA given twice daily over four days resulted in significantly decreased TBARS and significantly increased superoxide dismutase activity, further indicating the ability of HBO therapy to reduce lipid peroxidation and thus alleviate one of the major mechanisms of secondary injury. ${ }^{17}$

Many studies have shown that HBO-PC leads to upregulation of antioxidant enzyme levels after SCI. ${ }^{16,18,19,27,29}$ Nie et al. ${ }^{16}$ showed that HBO-PC increased catalase and superoxide dismutase after reperfusion and correlated with improved motor recovery, and this was reversed by administration of the catalase inhibitor, 3-amino1,2,4-triazole (AT), 1 hour before ischemia-reperfusion injury; furthermore, administration of dimethylthiourea (DMTU), a free radical scavenger, 1 hour prior to each daily HBO-PC caused a significant reduction in catalase and superoxide dismutase activities compared to the HBO + SCI group, indicating that the initial population of reactive oxygen species after HBO-PC may be responsible for activating the upregulation of antioxidant enzymes, which then reduce the oxidative stress associated with secondary injury post-SCI. Wang et al. ${ }^{19}$ also showed that superoxide dismutase and catalase increased after HBOPC in an ischemia-reperfusion SCI model in rats, and this led to decreased superoxide and hydrogen peroxide reactive oxygen species and correlated with improved motor recovery.

Heme oxygenase-1 is a heat shock protein (HSP32) that is increased within 24 hours after SCI. ${ }^{51,52}$ The enzyme catalyzes heme breakdown to carbon monoxide, iron, and biliverdin, with bilirubin production resulting from the subsequent reduction of biliverdin. ${ }^{53}$ Carbon monoxide, biliverdin, and bilirubin all have antioxidant properties, and heme oxygenase-1 has also been shown to protect against cell death by regulating iron. ${ }^{51,52,54}$ Accordingly, heme oxygenase-1 knockout mice have increased susceptibility to oxidative injury. ${ }^{55}$ In 2007 , an in vitro study utilizing primary culture mice spinal neurons showed that a single HBO-PC session significantly increased cell viability beginning at 4 hours after treatment, reduced DNA damage, and enhanced protein and mRNA expression of heme oxygenase-1; however, administration of tin-mesoporphyrin IX
(SnMP), a specific heme oxygenase-1 inhibitor, 10 minutes prior to HBO-PC completely reversed the neuroprotection, indicating that heme oxygenase-1 plays an important role in the ischemic tolerance induced by HBO-PC. ${ }^{18}$ Furthermore, HSPs are molecular chaperones that are important for repairing damaged proteins and have demonstrated to exert a beneficial effect after SCI by contributing to the attenuation of secondary injury. ${ }^{56}$ In another in vitro study utilizing primary culture rat spinal neurons in 2014, a single 60-minute HBO-PC session 12 hours before injury significantly increased cell viability and increased levels of HSP32, which peaked at 12 hours post-HBO exposure; administration of zinc protoporphyrin IX (Zn-pp), a specific HSP32 inhibitor, immediately prior to HBO-PC reversed the effect of HBO-PC on cell viability, further suggesting that upregulation of HSP32 contributes to the neuroprotective effect of HBO-PC. ${ }^{29}$

Nuclear factor erythroid 2-related factor $2(\mathrm{Nrf2})$ is a transcription factor involved in regulating the antioxidant response element (ARE), which governs the expression of antioxidant enzymes and is especially activated in astrocytes, thereby contributing to neuroprotection against oxidative stress after SCI. ${ }^{57-60}$ A 2014 study showed that at 12 and 24 hours after a single session of HBO-PC, Nrf2 $\mathrm{mRNA}$ /protein expression, DNA binding activity, and expression of downstream genes involved in glutathione synthesis were all significantly increased in the spinal cord compared to controls; furthermore, glutathione content in the spinal cord was significantly increased by HBO-PC compared to the SCI only group up to 48 hours after ischemia-reperfusion injury. ${ }^{27}$ Immunofluorescence staining of spinal cord tissue revealed greater Nrf2 immunoreactivity in astrocytes versus neurons, indicating that HBO-PC provides neuroprotection by upregulating Nrf2 specifically in astrocytes of the spinal cord. ${ }^{27}$

\section{$\mathrm{HBO}$ therapy reduces inflammation}

Many recent studies have investigated the effect of $\mathrm{HBO}$ on the inflammatory processes that follow SCI. ${ }^{20,24-26,31,32,34,35}$ In 2010, a rat model involving clip compression injury of the spinal cord at $\mathrm{T}_{8-9}$ showed decreased inflammatory cytokines, IL- $1 \beta$ and TNF- $\alpha$, and decreased myeloperoxidase (MPO), an indicator of neutrophil infiltration, after a single HBO treatment immediately after SCI; additionally, increased level of the anti-inflammatory cytokine IL-10 was observed in the HBO therapy group, indicating that HBO not only reduces inflammatory mediators, but also promotes an anti-inflammatory phenotype. ${ }^{20}$

Macrophages and microglia are the primary mediators of inflammation in the secondary injury following SCI. ${ }^{3}$ The macrophage response following after SCI is polar- 
ized, consisting mostly of the "classically activated" M1 macrophages that promote the production of inflammatory cytokines and free radicals, and very low expression of the "alternatively activated," anti-inflammatory M2 macrophages. ${ }^{61,62}$ The effect of multiple HBO treatments on macrophage polarization after clip compression of the spinal cord in a rat model was examined in 2015 and showed that HBO significantly decreases the M1 phenotype (iNOS and CD16/32 positive cells) and its corresponding Th1 cytokines, interferon (IFN)- $\beta$ and TNF- $\alpha$, and significantly increases the M2 phenotype (arginase- 1 and CD206 positive cells) and its corresponding Th2 cytokines, IL-4 and IL-13; these findings were accompanied by improved axonal growth, significantly greater myelin sparing, and greater functional recovery, indicating that HBO therapy provides neuroprotection by promoting the anti-inflammatory M2 phenotype and downregulating the inflammatory M1 phenotype. ${ }^{32}$

As previously mentioned, decreased neutrophil infiltration, monitored by decreased MPO, has been observed after HBO therapy of SCI. ${ }^{20,37}$ The study by Wang et al. ${ }^{37}$ further examined the effect of HBO therapy on the inflammatory cell response after SCI by monitoring monocyte chemoattractant protein-1 (MCP-1), a chemokine involved in recruiting monocytes and lymphocytes to sites of inflammation and increases following SCI. ${ }^{63}$ Inhibiting MCP-1 has shown to decrease mononuclear cell infiltration of injured spinal cord tissue, thereby decreasing inflammatory damage. ${ }^{64}$ In 2016, the upregulation of MCP-1 after SCI was significantly decreased by HBO therapy and correlated with improved neurological outcomes in a rat model, indicating that downregulation of MCP-1 is involved in the neuroprotective effects of HBO therapy after SCI. ${ }^{37}$

The effect of HBO therapy on NALP3 was previously discussed in the context of apoptosis, but in 2015, the role of the NALP3 inflammasome in the ability of HBO therapy to attenuate inflammation after SCI was investigated. The NALP3 inflammasome is a multimeric protein complex consisting of NALP3, ASC, and caspase-1, that mediates IL-1 $\beta$ production and release, which in turn induces further inflammatory cytokine release. ${ }^{65}$ Daily HBO therapy significantly decreased mRNA and protein expression of NALP3 at 1, 3, and 7 days post-SCI, whereas mRNA and protein levels of ASC and caspase-1 were significantly decreased at 3 and 7 days post-SCI; furthermore, IL- $1 \beta$ levels were also significantly reduced at 3 and 7 days post-SCI. ${ }^{35}$ Given that reactive oxygen species can trigger NALP3 inflammasome signaling in retinal pigment epithelial cells, Liang et al. ${ }^{35,66}$ proposed that the decreased expression of NALP3, ASC, caspase-1, and IL-1 $\beta$ after HBO therapy resulted from the previously evidenced ability of HBO therapy to decrease ROS generation.

Matrix metalloproteinases (MMPs) are zinc-containing endopeptidases that are synthesized in an inactive, zymogen, form and are involved in extracellular matrix degradation..$^{67}$ MMP-2 and MMP-9 stimulate the production of pro-inflammatory cytokines, thereby contributing to secondary injury post-SCI. ${ }^{68-71}$ In 2013 , HBO therapy postSCI resulted in significantly reduced MMP-2 and MMP-9 and correlated with decreased level of the inflammatory cytokine IL-6, indicating that the downregulation of MMPs plays a role in the neuroprotection provided by HBO. ${ }^{24}$

High-mobility group protein B1 (HMGB1) is a mediator of inflammation that is activated by inflammatory cytokines such as TNF- $\alpha$, and has been shown to increase after SCI. ${ }^{72,73}$ HMGB1 has been shown to stimulate toll like receptors (TLRs), receptor for advanced glycation end products (RAGE), and nuclear factor $\kappa \mathrm{B}(\mathrm{NF}-\kappa \mathrm{B})$, which in turn activates other inflammatory cytokines, including IL$1 \beta$ and TNF- $\alpha$, thereby contributing to inflammatory damage after SCI. ${ }^{74-77} \mathrm{HBO}$ therapy has the ability to reduce inflammation after SCI by significantly downregulating HMGB1 and its subsequent signaling cascades, including NF- $\kappa \mathrm{B}$ and its p65 component, TLR4, TLR2, RAGE, IL- $1 \beta$ and TNF- $\alpha .^{25,26,34}$

Gap junctions are specialized types of intercellular channels that allow for the passage of ions, molecules, and second messengers between adjacent cells. ${ }^{78}$ Connexins are the major structural units of gap junctions, and connexin43 (CX43) composes gap junctions within the central nervous system. ${ }^{79}$ Previous studies have shown that CX43 is upregulated in the injured spinal cord after SCI, allowing dissemination of injury mediators from damaged cells to surrounding healthy cells that survived the primary insult. ${ }^{80,81}$ In 2014, Liu et al. ${ }^{28}$ showed that daily HBO therapy after SCI significantly reduces mRNA and protein expression of CX43, thereby contributing to reduced inflammation by preventing the spread of inflammatory mediators from injured cells to healthy cells, as reported in other studies that have examined the role of CX43 and SCI. ${ }^{82,83}$

\section{HBO therapy promotes angiogenesis}

Vascular endothelial growth factor (VEGF) is important for angiogenesis in the CNS via stimulation of endothelial cell proliferation and migration, but VEGF is also important in promoting neuronal proliferation and neuroprotection. ${ }^{84}$ Tai et al. ${ }^{20}$ first reported that a single HBO treatment initiated immediately after SCI results in increased VEGF-positive cells at 4-7 days post-SCI. Since then, two other studies involving daily $\mathrm{HBO}$ treatments after SCI have also showed significantly increased VEGF compared to the SCI-only group. ${ }^{24,28}$ VEGF has previously been shown to increase 
after SCI to restore blood supply by increasing vascular density, thereby promoting neuronal protection and functional recovery; thus, the improved neurological recovery seen with HBO therapy of SCI may be, in part, due to increased expression of VEGF. ${ }^{85}$

\section{$\mathrm{HBO}$ therapy reduces spinal cord edema}

Recent studies have shown that HBO therapy significantly reduces spinal cord edema post-SCI. ${ }^{24,27,31}$ MMP-2 and MMP-9 were previously discussed in the context of inflammation, but these enzymes also cause increased permeability of the blood-spinal cord barrier via degradation of type IV collagen, leading to spinal cord edema. ${ }^{68,69}$ In 2013, twice daily HBO therapy after SCI in a rat model resulted in significantly decreased MMP-2 at 3 days post-SCI and MMP-9 levels at 2, 3, and 5 days post-SCI; spinal cord water content was also significantly decreased at 2 and 3 days post-SCI, suggesting the ability of HBO therapy to decrease spinal cord edema by downregulating metalloproteinases after SCI. ${ }^{24}$

In 2014, protein water channels called aquaporins were studied after HBO therapy of SCI. ${ }^{31}$ Rats treated with HBO beginning at 4 hours after SCI and continuing for a total of four times daily over three consecutive days were observed to have significantly reduced mRNA and protein expression of aquaporin 4 (AQP4) and aquaporin 9 (AQP9). ${ }^{31}$ Previous work has demonstrated the positive correlation between increased expression of AQP4 and increased spinal cord water content after SCI, and further studies showed that neurological outcome is greatly enhanced post-SCI in AQP4-null mice. ${ }^{86,87}$ Accordingly, a component of the decreased spinal cord edema after HBO therapy of SCI involves the downregulation of AQP4, which leads to reduced water entry into the spinal cord..$^{31}$

\section{HBO therapy increases autophagy}

Autophagy is a mechanism of intracellular degradation by which autophagosomes deliver cellular components that require degrading to lysosomes to maintain cellular homeostasis. ${ }^{88}$ Important factors for monitoring autophagy are beclin-1, a direct stimulator of autophagy, and light chain 3 type II (LC3-II), a protein that is directly proportional to the number of autophagic vacuoles. ${ }^{89,90}$ The first and only study on the effect of HBO therapy on autophagy after SCI showed that Beclin-1 and LC3-II significantly increase in injured spinal cord neurons and glial cells at three days after SCI in rats receiving daily HBO therapy. ${ }^{36}$ Further work is needed to elucidate the exact mechanism, but this first report by Sun et al. ${ }^{36}$ indicates that HBO therapy upregulates autophagy after SCI to promote repair and protection.

\section{Future Research}

While the benefits and potential neuroprotective mechanisms of HBO therapy in the treatment of SCI have been demonstrated in many experimental studies, very few clinical studies have been performed (Table 2). The most recent clinical study involved a total of 34 patients that suffered cervical hyperextension injury without bone damage. ${ }^{91}$ In this retrospective study, the 13 patients that received 85 minutes of HBO therapy at 2.0 ATA once daily for ten days were found to have significantly higher improvement rates indicated by the Neurological Cervical Spine Scale (NCSS) versus the non-HBO group of 21 patients. ${ }^{91}$ In the first clinical study of HBO therapy of SCI in 1977, 13 patients with compressive SCI that experienced persistent neurological deficits after surgery received between ten and $15 \mathrm{HBO}$ treatments given at 1.5 ATA for 40 minutes each; 6 of these patients had significant motor improvement, but the other 7 patients did not display significant neurological change. ${ }^{92}$ A year later, two studies involving complete and partial spinal cord lesions showed that HBO therapy at 2.5 ATA administered within 14 hours at most resulted in varying degrees of neurological improvement. ${ }^{93,94}$ Although the study by Gamache et al. ${ }^{95}$ in 1981 did not show a significant change in recovery rate in patients treated with HBO therapy versus conventional therapy, a later report by $\mathrm{Yeo}^{96}$ showed that 15 of 27 patients with upper motor neuron SCI had meaningful functional recovery after 2-3 HBO treatments within 20 hours of injury.

Unlike experimental studies, these clinical reports demonstrate mixed results regarding the utility of HBO therapy after SCI. Future studies should address some of the underlying factors that may account for the discrepancies between experimental and clinical outcomes.

First, the optimal onset, duration, frequency, and pressure of HBO therapy after SCI require further investigation. Although many treatment paradigms have been studied in experimental models (Table 1), no single study has focused on comparing the efficacy these various paradigms in the context of SCI. This is an important area of research given that the heterogeneity of treatment paradigms employed by clinical studies is a factor that complicates the interpretation of outcomes and presents an obstacle in comparing multiple studies.

Second, while each experimental study utilized a single method of homogeneous, reproducible SCI (Table 1), spinal cord injuries in clinical practice are heterogeneous and thus may respond differently to HBO therapy. A single experimental study comparing the effect of HBO therapy on multiple injury models could shed light on the possible need for different $\mathrm{HBO}$ paradigms for certain types of injuries, 


\begin{tabular}{|c|c|c|c|c|}
\hline Author & Year & Injury type & HBO paradigm & Outcome \\
\hline Holbach et al. ${ }^{92}$ & 1977 & Compression injury & $\begin{array}{l}\text { 1.5 ATA for } 40 \text { minutes, } 10-15 \\
\text { treatments }\end{array}$ & $\begin{array}{l}\text { Significant motor improvement in six } \\
\text { patients }\end{array}$ \\
\hline Jones et al. ${ }^{94}$ & 1978 & $\begin{array}{l}\text { Complete or partial spinal cord } \\
\text { transection between C6-12 }\end{array}$ & $\begin{array}{l}2.5 \text { ATA for } 120 \text { minutes, two } \\
\text { treatments, onset within } 12 \text { hours }\end{array}$ & $\begin{array}{l}\text { Neurological improvement in five } \\
\text { patients and functional improvement in } \\
\text { two patients }\end{array}$ \\
\hline Yeo et al. ${ }^{93}$ & 1978 & $\begin{array}{l}\text { Complete or partial spinal cord } \\
\text { lesion }\end{array}$ & $\begin{array}{l}2.5 \text { ATA for } 90 \text { minutes, two } \\
\text { treatments, onset within } 14 \text { hours }\end{array}$ & $\begin{array}{l}\text { Faster and greater recovery in five } \\
\text { patients }\end{array}$ \\
\hline Gamache et al. ${ }^{95}$ & 1981 & $\begin{array}{l}\text { Complete or partial spinal cord } \\
\text { lesion }\end{array}$ & $\begin{array}{l}\text { Two groups: one received } 2.5 \text { ATA } \\
\text { and the other received 2.0 ATA. See } \\
\text { reference for timing details }\end{array}$ & $\begin{array}{l}\text { No significant change in recovery } \\
\text { rate compared to patients receving } \\
\text { conventional therapy }\end{array}$ \\
\hline Yeo $^{96}$ & 1984 & Upper motor neuron SCI & $\begin{array}{l}2.5 \text { ATA for } 90 \text { minutes, two to three } \\
\text { treatments, average onset within } \\
\text { nine hours of SCI }\end{array}$ & $\begin{array}{l}\text { Meaningful functional recovery in } 15 \\
\text { patients }\end{array}$ \\
\hline Asamoto et al. ${ }^{91}$ & 2000 & $\begin{array}{l}\text { Cervical hyperextension without } \\
\text { bone damage }\end{array}$ & $\begin{array}{l}\text { 2.0 ATA for } 85 \text { minutes once daily } \\
\text { for ten days; onset within } 24 \text { hours } \\
\text { post-SCI }\end{array}$ & $\begin{array}{l}\text { Significantly higher improvement rate } \\
\text { indicated by NCSS }\end{array}$ \\
\hline
\end{tabular}

Note: HBO: Hyperbaric oxygen; SCI: spinal cord injury; ATA: atmospheres absolute; NCSS: Neurological Cervical Spine Scale.

and such a study may also help explain the conflicting results observed in the clinical reports of HBO therapy post-SCI to this date. ${ }^{91-96}$

Third, many clinical studies have been performed to evaluate the effect of HBO-PC on brain injury, but few studies have focused on the clinical application of HBO-PC to protect against SCI, especially in the context of spinal cord protection during neurosurgical procedures. ${ }^{97}$ Given that most experimental studies have focused on post-SCI HBO therapy rather than-PC (Table 1), further experimental research of HBO-PC prior to SCI should be performed before conducting clinical studies.

Finally, given that previous clinical studies have involved small patient samples, future studies with larger sets of patients are required to adequately gauge the effectiveness of HBO therapy for SCI in clinical practice.

\section{Conclusion}

HBO therapy has been shown to exert neuroprotective effects when administered before or after SCI. Experimental studies have revealed various mechanisms that contribute to these neuroprotective effects, including improved spinal cord oxygen tension, decreased apoptosis, reduced inflammation, attenuation of oxidative stress, and improved angiogenesis and autophagy. However, even though HBO therapy of SCI is a promising treatment based on results of experimental studies, only a few clinical reports have been performed and have shown conflicting outcomes, thereby warranting further studies to elucidate the optimal HBO treatment paradigm and to determine if the treatment paradigm should depend on the specific type of SCI.

\section{Author contributions}

JHH planned the manuscript. NPP wrote the manuscript under the guidance of JHH. NPP performed literature search and analysis. JHH edited and finalized the manuscript. JHH and NPP both contributed to revisions of the manuscript.

\section{Conflicts of interest}

None declared.

Open access statement

This is an open access article distributed under the terms of the Creative Commons Attribution-NonCommercialShareAlike 3.0 License, which allows others to remix, tweak, and build upon the work non-commercially, as long as the author is credited and the new creations are licensed under the identical terms.

Contributor agreement

A statement of "Publishing Agreement" has been signed by an authorized author on behalf of all authors prior to publication.

\section{Plagiarism check}

This paper has been checked twice with duplicationchecking software iThenticate.

\section{Peer review}

A double-blind and stringent peer review process has been performed to ensure the integrity, quality and significance of this paper.

Open peer reviewer

Xue-jun Sun, Second Military Medical University, China. 


\section{RefERENCES}

1. Jain NB, Ayers GD, Peterson EN, et al. Traumatic spinal cord injury in the United States, 1993-2012. JAMA. 2015;313:22362243.

2. SCI facts and figures 2014. J Spinal Cord Med. 2015;38:124125.

3. Kwon BK, Tetzlaff W, Grauer JN, Beiner J, Vaccaro AR. Pathophysiology and pharmacologic treatment of acute spinal cord injury. Spine J. 2004;4:451-464.

4. Zhou X, He X, Ren Y. Function of microglia and macrophages in secondary damage after spinal cord injury. Neural Regen Res. 2014;9:1787-1795.

5. Liu NK, Xu XM. Neuroprotection and its molecular mechanism following spinal cord injury. Neural Regen Res. 2012:7(26):2051-2062.

6. Kubeck JP, Merola A, Mathur S, et al. End organ effects of high-dose human equivalent methylprednisolone in a spinal cord injury rat model. Spine (Phila Pa 1976). 2006;31:257261.

7. Wang Y, Zhang S, Luo M, Li Y. Hyperbaric oxygen therapy improves local microenvironment after spinal cord injury. Neural Regen Res. 2014;9:2182-2188.

8. Thom SR. Hyperbaric oxygen: its mechanisms and efficacy. Plast Reconstr Surg. 2011;127 Suppl 1:131S-141S.

9. Murakami N, Horinouchi T, Sakurai M, et al. Hyperbaric oxygen therapy given 30 minutes after spinal cord ischemia attenuates selective motor neuron death in rabbits. Crit Care Med. 2001;29:814-818.

10. Mathieu D. Handbook on Hyperbaric Medicine. Berlin: Springer Netherlands; 2006.

11. Kelly DL Jr, Lassiter KR, Vongsvivut A, Smith JM. Effects of hyperbaric oxygenation and tissue oxygen studies in experimental paraplegia. J Neurosurg. 1972;36:425-429.

12. Anderson DK, Hall ED. Pathophysiology of spinal cord trauma. Ann Emerg Med. 1993;22:987-992.

13. McDonald JW, Sadowsky C. Spinal-cord injury. Lancet. 2002;359:417-425.

14. Tator $\mathrm{CH}$, Fehlings MG. Review of the secondary injury theory of acute spinal cord trauma with emphasis on vascular mechanisms. J Neurosurg. 1991;75:15-26.

15. Yu Y, Matsuyama Y, Yanase M, et al. Effects of hyperbaric oxygen on GDNF expression and apoptosis in spinal cord injury. Neuroreport. 2004;15:2369-2373.

16. Nie H, Xiong L, Lao N, Chen S, Xu N, Zhu Z. Hyperbaric oxygen preconditioning induces tolerance against spinal cord ischemia by upregulation of antioxidant enzymes in rabbits. $J$ Cereb Blood Flow Metab. 2006;26:666-674.

17. Kahraman S, Duz B, Kayali H, et al. Effects of methylprednisolone and hyperbaric oxygen on oxidative status after experimental spinal cord injury: a comparative study in rats. Neurochem Res. 2007;32:1547-1551.

18. Li Q, Li J, Zhang L, Wang B, Xiong L. Preconditioning with hyperbaric oxygen induces tolerance against oxidative injury via increased expression of heme oxygenase- 1 in primary cultured spinal cord neurons. Life Sci. 2007;80:1087-1093.

19. Wang L, Li W, Kang Z, et al. Hyperbaric oxygen preconditioning attenuates early apoptosis after spinal cord ischemia in rats. $J$ Neurotrauma. 2009;26:55-66.
20. Tai PA, Chang CK, Niu KC, Lin MT, Chiu WT, Lin CM. Attenuating experimental spinal cord injury by hyperbaric oxygen: stimulating production of vasculoendothelial and glial cell line-derived neurotrophic growth factors and interleukin- 10. J Neurotrauma. 2010;27:1121-1127.

21. Topuz K, Colak A, Cemil B, et al. Combined hyperbaric oxygen and hypothermia treatment on oxidative stress parameters after spinal cord injury: an experimental study. Arch Med Res. 2010;41:506-512.

22. Dayan K, Keser A, Konyalioglu S, et al. The effect of hyperbaric oxygen on neuroregeneration following acute thoracic spinal cord injury. Life Sci. 2012;90:360-364.

23. Lu PG, Hu SL, Hu R, et al. Functional recovery in rat spinal cord injury induced by hyperbaric oxygen preconditioning. Neurol Res. 2012;34:944-951.

24. Yang J, Wang G, Gao C, Shao G, Kang N. Effects of hyperbaric oxygen on MMP-2 and MMP-9 expression and spinal cord edema after spinal cord injury. Life Sci. 2013;93:1033-1038.

25. Yang J, Liu X, Zhou Y, Wang G, Gao C, Su Q. Hyperbaric oxygen alleviates experimental (spinal cord) injury by downregulating HMGB1/NF-kappaB expression. Spine (Phila Pa 1976). 2013;38:E1641-1648.

26. Tan J, Zhang F, Liang F, et al. Protective effects of hyperbaric oxygen treatment against spinal cord injury in rats via tolllike receptor 2/nuclear factor-kappaB signaling. Int J Clin Exp Pathol. 2014;7:1911-1919.

27. Xu J, Huang G, Zhang K, et al. Nrf2 activation in astrocytes contributes to spinal cord ischemic tolerance induced by hyperbaric oxygen preconditioning. J Neurotrauma. 2014;31:1343-1353.

28. Liu X, Zhou Y, Wang Z, Yang J, Gao C, Su Q. Effect of VEGF and $\mathrm{CX} 43$ on the promotion of neurological recovery by hyperbaric oxygen treatment in spinal cord-injured rats. Spine J. 2014;14:119-127.

29. Huang G, Xu J, Xu L, et al. Hyperbaric oxygen preconditioning induces tolerance against oxidative injury and oxygen-glucose deprivation by up-regulating heat shock protein 32 in rat spinal neurons. PLoS One. 2014;9:e85967.

30. Long Y, Liang F, Gao C, Li Z, Yang J. Hyperbaric oxygen therapy reduces apoptosis after spinal cord injury in rats. Int $J$ Clin Exp Med. 2014;7:4073-4081.

31. Wang Y, Zhang S, Luo M, Li Y. Hyperbaric oxygen therapy improves local microenvironment after spinal cord injury. Neural Regen Res. 2014;9:2182-2188.

32. Geng CK, Cao HH, Ying X, Zhang HT, Yu HL. The effects of hyperbaric oxygen on macrophage polarization after rat spinal cord injury. Brain Res. 2015;1606:68-76.

33. Liu X, Yang J, Li Z, et al. Hyperbaric oxygen treatment protects against spinal cord injury by inhibiting endoplasmic reticulum stress in rats. Spine (Phila Pa 1976). 2015;40:E1276-1283.

34. Kang N, Hai Y, Yang J, Liang F, Gao CJ. Hyperbaric oxygen intervention reduces secondary spinal cord injury in rats via regulation of HMGB1/TLR4/NF-kappaB signaling pathway. Int J Clin Exp Pathol. 2015;8:1141-1153.

35. Liang F, Li C, Gao C, et al. Effects of hyperbaric oxygen therapy on NACHT domain-leucine-rich-repeat- and pyrin domain-containing protein 3 inflammasome expression in rats following spinal cord injury. Mol Med Rep. 2015;11:46504656. 
36. Sun Y, Liu D, Su P, Lin F, Tang Q. Changes in autophagy in rats after spinal cord injury and the effect of hyperbaric oxygen on autophagy. Neurosci Lett. 2016;618:139-145.

37. Wang Y, Li C, Gao C, et al. Effects of hyperbaric oxygen therapy on RAGE and MCP-1 expression in rats with spinal cord injury. Mol Med Rep. 2016;14:5619-5625.

38. Emery E, Aldana P, Bunge MB, et al. Apoptosis after traumatic human spinal cord injury. J Neurosurg. 1998;89:911-920.

39. Satake K, Matsuyama Y, Kamiya M, et al. Nitric oxide via macrophage iNOS induces apoptosis following traumatic spinal cord injury. Brain Res Mol Brain Res. 2000;85:114-122.

40. Ehrlich LC, Peterson PK, Hu S. Interleukin (IL)-1beta-mediated apoptosis of human astrocytes. Neuroreport. 1999;10:1849-1852.

41. Fankhauser C, Friedlander RM, Gagliardini V. Prevention of nuclear localization of activated caspases correlates with inhibition of apoptosis. Apoptosis. 2000;5:117-132.

42. Genovese T, Mazzon E, Crisafulli C, et al. Immunomodulatory effects of etanercept in an experimental model of spinal cord injury. J Pharmacol Exp Ther. 2006;316:1006-1016.

43. Inohara N, Nunez G. The NOD: a signaling module that regulates apoptosis and host defense against pathogens. Oncogene. 2001;20:6473-6481.

44. Vince JE, Wong WW, Gentle I, et al. Inhibitor of apoptosis proteins limit RIP3 kinase-dependent interleukin-1 activation. Immunity. 2012;36:215-227.

45. Nishitoh H. CHOP is a multifunctional transcription factor in the ER stress response. J Biochem. 2012;151:217-219.

46. Nakagawa T, Zhu H, Morishima N, et al. Caspase-12 mediates endoplasmic-reticulum-specific apoptosis and cytotoxicity by amyloid-beta. Nature. 2000;403:98-103.

47. Hitomi J, Katayama T, Taniguchi M, Honda A, Imaizumi K, Tohyama M. Apoptosis induced by endoplasmic reticulum stress depends on activation of caspase-3 via caspase-12. Neurosci Lett. 2004;357:127-130.

48. Anggård E. Nitric oxide: mediator, murderer, and medicine. Lancet. 1994;343:1199-1206.

49. Huang PL. Nitric oxide and cerebral ischemic preconditioning. Cell Calcium. 2004;36:323-329.

50. Christie SD, Comeau B, Myers T, Sadi D, Purdy M, Mendez I. Duration of lipid peroxidation after acute spinal cord injury in rats and the effect of methylprednisolone. Neurosurg Focus. 2008;25:E5.

51. Mautes AE, Kim DH, Sharp FR, et al. Induction of heme oxygenase-1 (HO-1) in the contused spinal cord of the rat. Brain Res. 1998;795:17-24.

52. Mautes AE, Bergeron M, Sharp FR, et al. Sustained induction of heme oxygenase-1 in the traumatized spinal cord. Exp Neurol. 2000;166:254-265.

53. Kikuchi G, Yoshida T, Noguchi M. Heme oxygenase and heme degradation. Biochem Biophys Res Commun. 2005;338:558567.

54. Ferris CD, Jaffrey SR, Sawa A, et al. Haem oxygenase-1 prevents cell death by regulating cellular iron. Nat Cell Biol. 1999;1:152-157.

55. Chen-Roetling J, Benvenisti-Zarom L, Regan RF. Cultured astrocytes from heme oxygenase-1 knockout mice are more vulnerable to heme-mediated oxidative injury. J Neurosci Res. 2005;82:802-810.
56. Reddy SJ, La Marca F, Park P. The role of heat shock proteins in spinal cord injury. Neurosurg Focus. 2008;25:E4.

57. Kaspar JW, Niture SK, Jaiswal AK. Nrf2:INrf2 (Keap1) signaling in oxidative stress. Free Radic Biol Med. 2009;47:13041309.

58. Shih AY, Johnson DA, Wong G, et al. Coordinate regulation of glutathione biosynthesis and release by Nrf2-expressing glia potently protects neurons from oxidative stress. J Neurosci. 2003;23:3394-3406.

59. Vargas MR, Johnson JA. The Nrf2-ARE cytoprotective pathway in astrocytes. Expert Rev Mol Med. 2009;11:e17.

60. Wang X, de Rivero Vaccari JP, Wang H, et al. Activation of the nuclear factor E2-related factor 2/antioxidant response element pathway is neuroprotective after spinal cord injury. $\mathrm{J} \mathrm{Neu-}$ rotrauma. 2012;29:936-945.

61. Kigerl KA, Gensel JC, Ankeny DP, Alexander JK, Donnelly DJ, Popovich PG. Identification of two distinct macrophage subsets with divergent effects causing either neurotoxicity or regeneration in the injured mouse spinal cord. $J$ Neurosci. 2009;29:13435-13444.

62. David S, Kroner A. Repertoire of microglial and macrophage responses after spinal cord injury. Nat Rev Neurosci. 2011;12:388-399.

63. Liu SQ, Ma YG, Peng H, Fan L. Monocyte chemoattractant protein-1 level in serum of patients with acute spinal cord injury. Chin J Traumatol. 2005;8:216-219.

64. Zhang X, Chen C, Ma S, Wang Y, Zhang X, Su X. Inhibition of monocyte chemoattractant peptide-1 decreases secondary spinal cord injury. Mol Med Rep. 2015;11:4262-4266.

65. Lamkanfi M, Dixit VM. Inflammasomes: guardians of cytosolic sanctity. Immunol Rev. 2009;227:95-105.

66. Kauppinen A, Niskanen H, Suuronen T, Kinnunen K, Salminen A, Kaarniranta K. Oxidative stress activates NLRP3 inflammasomes in ARPE-19 cells--implications for age-related macular degeneration (AMD). Immunol Lett. 2012;147:29-33.

67. Visse R, Nagase H. Matrix metalloproteinases and tissue inhibitors of metalloproteinases: structure, function, and biochemistry. Circ Res. 2003;92:827-839.

68. Noble LJ, Donovan F, Igarashi T, Goussev S, Werb Z. Matrix metalloproteinases limit functional recovery after spinal cord injury by modulation of early vascular events. $J$ Neurosci. 2002;22:7526-7535.

69. Agrawal SM, Lau L, Yong VW. MMPs in the central nervous system: where the good guys go bad. Semin Cell Dev Biol. 2008;19:42-51.

70. Winkler EA, Sengillo JD, Bell RD, Wang J, Zlokovic BV. Blood-spinal cord barrier pericyte reductions contribute to increased capillary permeability. J Cereb Blood Flow Metab. 2012;32:1841-1852.

71. Jang JW, Lee JK, Kim SH. Activation of matrix metalloproteinases-9 after photothrombotic spinal cord injury model in rats. $J$ Korean Neurosurg Soc. 2011;50:288-292.

72. Yang H, Wang H, Czura CJ, Tracey KJ. The cytokine activity of HMGB1. J Leukoc Biol. 2005;78:1-8.

73. Kawabata H, Setoguchi T, Yone K, et al. High mobility group box 1 is upregulated after spinal cord injury and is associated with neuronal cell apoptosis. Spine (Phila Pa 1976). 2010;35:1109-1115. 
74. van Beijnum JR, Buurman WA, Griffioen AW. Convergence and amplification of toll-like receptor (TLR) and receptor for advanced glycation end products (RAGE) signaling pathways via high mobility group B1 (HMGB1). Angiogenesis. 2008; 11:91-99.

75. Xie J, Mendez JD, Mendez-Valenzuela V, Aguilar-Hernandez MM. Cellular signalling of the receptor for advanced glycation end products (RAGE). Cell Signal. 2013;25:2185-2197.

76. Kwon BK, Stammers AM, Belanger LM, et al. Cerebrospinal fluid inflammatory cytokines and biomarkers of injury severity in acute human spinal cord injury. $J$ Neurotrauma. 2010;27:669-682.

77. Chen KB, Uchida K, Nakajima H, et al. High-mobility group box-1 and its receptors contribute to proinflammatory response in the acute phase of spinal cord injury in rats. Spine (Phila Pa 1976). 2011;36:2122-2129.

78. Chew SS, Johnson CS, Green CR, Danesh-Meyer HV. Role of connexin43 in central nervous system injury. Exp Neurol. 2010;225:250-261.

79. Nagy JI, Rash JE. Connexins and gap junctions of astrocytes and oligodendrocytes in the CNS. Brain Res Rev. 2000;32:2944.

80. Lee IH, Lindqvist E, Kiehn O, Widenfalk J, Olson L. Glial and neuronal connexin expression patterns in the rat spinal cord during development and following injury. J Comp Neurol. 2005; 489:1-10.

81. Theriault E, Frankenstein UN, Hertzberg EL, Nagy JI. Connexin43 and astrocytic gap junctions in the rat spinal cord after acute compression injury. J Comp Neurol. 1997;382:199-214.

82. Cronin M, Anderson PN, Cook JE, Green CR, Becker DL. Blocking connexin43 expression reduces inflammation and improves functional recovery after spinal cord injury. Mol Cell Neurosci. 2008;39:152-160.

83. O'Carroll SJ, Alkadhi M, Nicholson LF, Green CR. Connexin 43 mimetic peptides reduce swelling, astrogliosis, and neuronal cell death after spinal cord injury. Cell Commun Adhes. 2008; 15:27-42.

84. Storkebaum E, Lambrechts D, Carmeliet P. VEGF: once regarded as a specific angiogenic factor, now implicated in neuroprotection. Bioessays. 2004;26:943-954.
85. Widenfalk J, Lipson A, Jubran M, et al. Vascular endothelial growth factor improves functional outcome and decreases secondary degeneration in experimental spinal cord contusion injury. Neuroscience. 2003;120:951-960.

86. Saadoun S, Bell BA, Verkman AS, Papadopoulos MC. Greatly improved neurological outcome after spinal cord compression injury in AQP4-deficient mice. Brain. 2008;131:1087-1098.

87. Nesic O, Lee J, Ye Z, et al. Acute and Chronic Changes in Aquaporin 4 Expression After Spinal Cord Injury. Neuroscience. 2006;143:779-792.

88. Mizushima N. Autophagy: process and function. Genes Dev. 2007;21:2861-2873.

89. Tanida I, Ueno T, Kominami E. LC3 conjugation system in mammalian autophagy. Int J Biochem Cell Biol. 2004;36:2503-2518.

90. Edinger AL, Thompson CB. Defective autophagy leads to cancer. Cancer Cell. 2003;4:422-424.

91. Asamoto S, Sugiyama H, Doi H, Iida M, Nagao T, Matsumoto $\mathrm{K}$. Hyperbaric oxygen (HBO) therapy for acute traumatic cervical spinal cord injury. Spinal Cord. 2000;38:538-540.

92. Holbach KH, Wassmann H, Linke D. The use of hyperbaric oxygenation in the treatment of spinal cord lesions. Eur Neurol. 1977;16:213-221.

93. Yeo JD, Lowry C, McKenzie B. Preliminary report on ten patients with spinal cord injuries treated with hyperbaric oxygen. Med J Aust. 1978;2:572-573.

94. Jones RF, Unsworth IP, Marosszeky JE. Hyperbaric oxygen and acute spinal cord injuries in humans. Med J Aust. 1978;2:573575.

95. Gamache FW Jr, Myers RA, Ducker TB, Cowley RA. The clinical application of hyperbaric oxygen therapy in spinal cord injury: a preliminary report. Surg Neurol. 1981;15:85-87.

96. Yeo JD. The use of hyperbaric oxygen to modify the effects of recent contusion injury to the spinal cord. Cent Nerv Syst Trauma. 1984;1:161-165.

97. Hu Q, Manaenko A, Matei N, et al. Hyperbaric oxygen preconditioning: a reliable option for neuroprotection. Med Gas Res. 2016;6:20-32. 